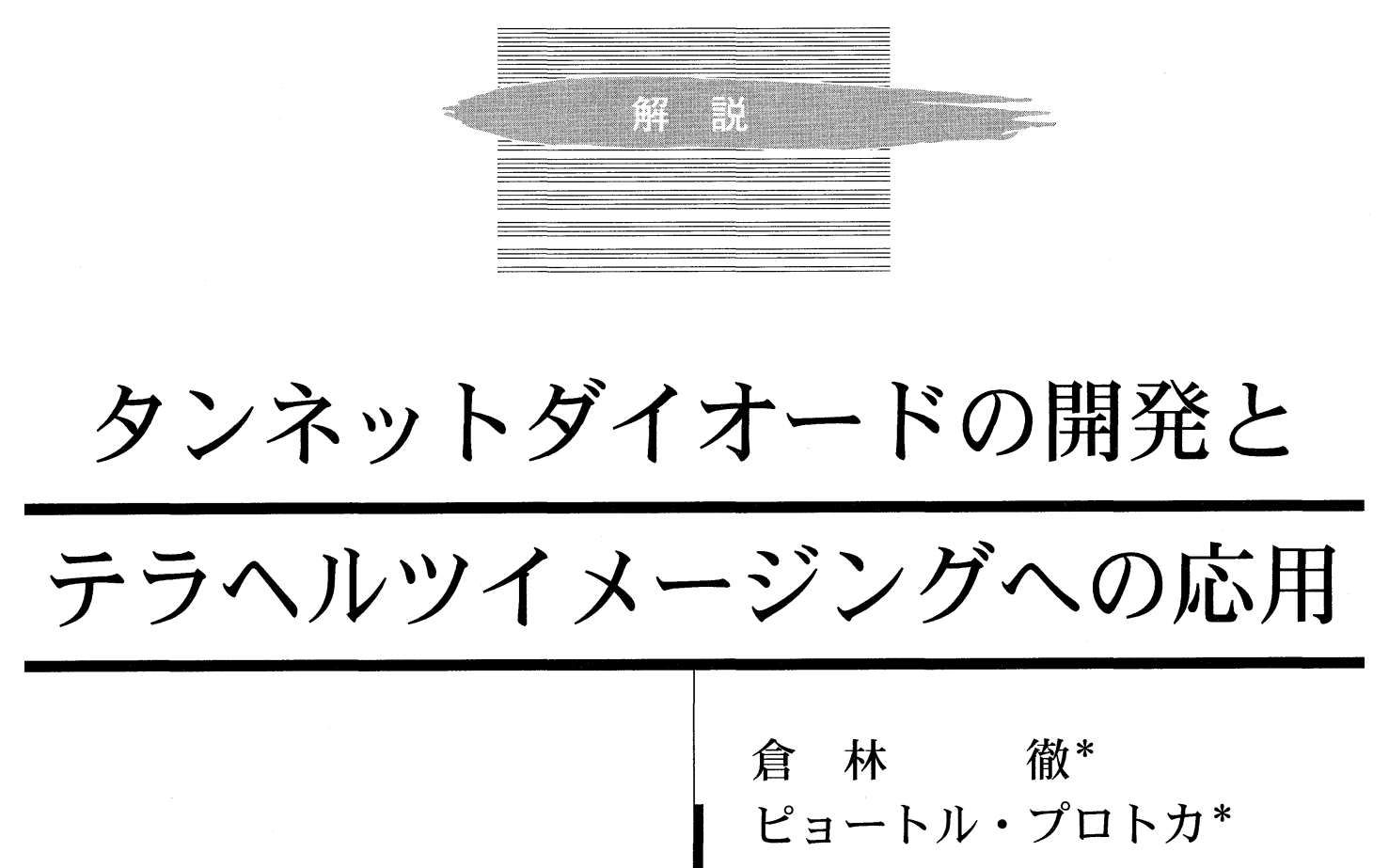

1. は じめに

タンネット(TUNNETT) ダイオードは, トンネル注入走 行時間効果(Tunnel injection Transit Time)を利用した負性 抵抗ダイオードであり，テラヘルツ帯で室温連続発振可能な 小型電子デバイスである. 半導体中のキャリアの走行時間効 果を用いた負性抵抗ダイオードは, 西澤が1953年に初めて 提案し(1)，1968年に GaAs p ${ }^{+} \mathrm{n}$ 構造によりパルス発振を実 現した ${ }^{(2)}$. 近年, 分子層エピタキシャル成長方法 ${ }^{(3)(4)}$ (MLE: Molecular Layer Epitaxy)を取り入れ各層の厚さを分 子層レベルで制御した薄膜構造を実現し, テラヘルッ領域で の高周波発振が可能になった ${ }^{(5)-(7)}$. 基本波による連続発振 素子は, 変調可能なワイヤレス通信用発振素子, さらにはテ ラヘルツを用いた検査装置としてより小型の電子デバイスが 最終応用形態と考えられ，その開発動向は世界中で注目され ている. タンネットダイオードはミリ波側からの電子デバイ スによる室温テラヘルツ発振可能な素子の最有力候補であ
る. 本報告では, タンネットダイオードの開発状況とコンパ クトなコヒーレント光源としての非破壊検查等への適用例, およびその将来性を紹介する。

\section{2. テラヘルツデバイスの開発状況}

テラヘルツ帯は図 1 に示すように, 光波帯と電波帯の境界 に位置し,これまで発生法の存在しない未踏波領域と呼ばれ てきた. エネルギー的な観点からは, 物質構成分子の電子ス ペクトルが, 可視・紫外から X 線領域に存在するのに対 し，テラヘルツ帯は分子の振動㧍よび回転スペクトルのエネ ルギー帯に相当する. 言い換えれば, テラヘルッ帯はこれま で赤外分光分析で見過ごされてきた生体関連分子を含む高分 子材料の骨格振動の固有振動に相当するので, これら分子の 識別や検出に利用できる. またテラヘルツ波は光波としての 直進性と電波としての透過性を兼社備えており, 光波にはな い優れた物質透過能を有することから，X線に代わる安全 な非破壞検査用光源としての有効性が認識されつつある.

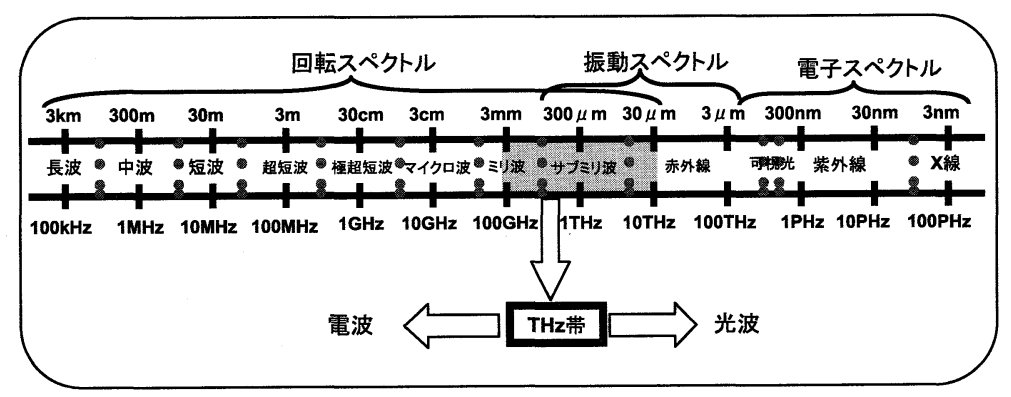

図 1 テラヘルツ領域.

\footnotetext{
* 財団法人半導体研究振興会主任研究員 (

Development of TUNNETT Diode and Its Application for Terahertz Imaging; Toru Kurabayashi, Piotr Płotka (Semiconductor Research Institute, Sendai)

Keywords: electronic device, tunnel injection transit time (TUNNETT) diode, sub-terahertz oscillation, fundamental continuous-wave oscillation, transmission imaging, reflection imaging, nondestructive inspection, molecular layer epitaxy 2006 年 5 月 30 日受理
} 
テラヘルツ波の発生法に関しては，1963年に化合物の分 子振動あるいはフォノンを励起してコヒーレントなテラヘル ツ電磁波を発生する提案が西澤によってなされている( ${ }^{(8)}$. 1979年には半導体ラマンレーザ発振を実現し，1983年には 周波数 $12.1 \mathrm{THz}$ のテラヘルツ電磁波発生に成功してい る(9). 他に, テラヘルツ光源として自由電子レーザや $\mathrm{p}-\mathrm{Ge}$ レーザがあるが，巨大な設備や極低温を必要とするため，基 礎研究における用途に限られている. 西澤等はさらに, テラ ヘルツ周波数で振動する半導体中の光学フォノン(格子振動) を活用してテラヘルツ電磁波を発生させる研究を進め, 半導 体 $\mathrm{GaP}$ 結晶を用いて，フォノンーポラリトンを励起すること によって，0.5 THz から $7 \mathrm{THz}$ に達する広い範囲において 高出力(高輝度)のテラヘルツ波を発生する周波数掃引型光源 の開発に成功し，テラヘルツ分子スペクトル計測装置を開発 した(10)(11).

半導体 $\mathrm{GaP}$ 結晶の代わりに誘電体 $\mathrm{LiNbO}_{3}$ 結晶を用いた パラメトリック発振 $(0.3-2.5 \mathrm{THz})$ が開発され実用化に向け た研究が行われている(12). また有機結晶であるジメチルア ミノスチルバゾリウムトシレイト (DAST)を用いた差周波混 合 (2-20 THz)のテラヘルツ波発生が報告されているが(13)， 実用化に関しては課題が残されている.

電子デバイスは軽量・小型化・低価格化が可能であるため にテラヘルツ波応用技術における実用化レベルあるいは製品 レベルで真価を発揮するものと考えられる. タンネットダイ オードは基本波による室温連続発振の最高周波数が 700 $\mathrm{GHz}$ を越え, テラヘルツ波発振可能な電子デバイスの最有 力候補である. 一方, 最近開発された共鳴トンネルダイオー ド(Resonant Tunneling Diode; RTD)でも最高発振周波数 $712 \mathrm{GHz}$ に達し(14)，コンパクトなコヒーレント光源として 開発が進められている(15). また, 最近になって, 光デバイ ス側からの低周波化が急速に進められ，量子カスケードレー ザのテラヘルツ帯発振が実現され(16)(17)，ミリ波からの電子 デバイス開発状況を合わせると，ここ数年のうちに半導体素 子による未踏破のテラヘルツ帯ギャップが埋まるものと思わ れる。

\section{3. タンネットダイオードの開発}

図 2 にタンネットダイオードの構造, 電界分布および電流 成分を模式的に示した。 タンネットダイオードは GaAs など を材料とした $\mathrm{p}^{+} \mathrm{n}^{+} \mathrm{n}^{-} \mathrm{n}^{+}$構造によって構成される．タンネ ット内部の電界強度は，急峻な $\mathrm{p}^{+} \mathrm{n}^{+}$接合による電子の高効 率トンネル注入に加え, 電子が走行する $\mathrm{n}^{-}$走行層に分布し ている.タンネットにおけるトンネリングによる注入電子は 位相が $\pi / 2$ の最大高周波電圧時に注入され，この電子が走 行層を走る際の走行時間効果によって生じる誘導電流によ り，位相角が $(3 / 2) \pi$ の時にダイオード外部に発生する高周 波電圧と誘導電流は逆位相になるため, 負性抵抗が最大とな る.バイアス条件を選択することによりダイオードの負性抵 抗特性を用い, 適した共振器構造内に設置することによって 基本波による室温連続発振を生じさせることができる. 走行

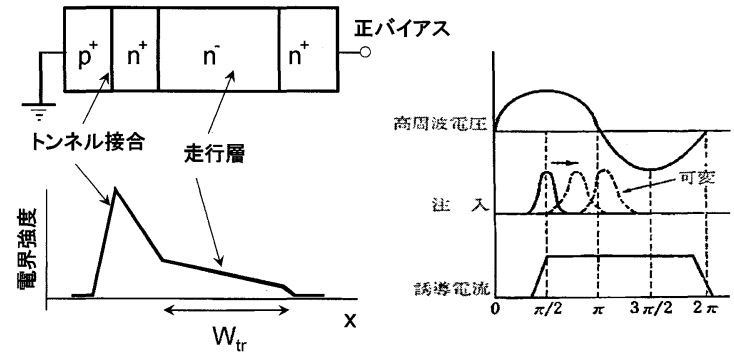

図 2 タンネットダイオードの構造，電界分布，およ び電流成分を表す模式図。

層内をドリフトする電子の速度を $\mathrm{V}_{\mathrm{t}}$, 走行領域の長さを $\mathrm{W}_{\mathrm{tr}}$ とすると, 発振周波数 $f_{\mathrm{OSC}}$ は

$$
f_{\mathrm{OSC}}=3 \mathrm{~V}_{\mathrm{t}} / 4 \mathrm{~W}_{\mathrm{tr}}
$$

となる. ここで, $\mathrm{V}_{\mathrm{t}}$ を $8 \times 10^{6} \mathrm{~cm} / \mathrm{s}, \mathrm{W}_{\mathrm{tr}}$ を $75 \mathrm{~nm}$ とすると， $f_{\mathrm{OSC}}=0.8 \mathrm{THz}$ となるので, $\mathrm{W}_{\mathrm{tr}}$ を結晶成長における厚みで 精密制御すれば， $1 \mathrm{THz}$ 以上の発振特性を制御性良く得る ことが可能になる.このため，タンネットダイオードの作製 においては，急峻な $\mathrm{p}^{+} \mathrm{n}^{+}$接合を持ち，逆バイアス時に $\mathrm{n}^{+}$ 層が空乏化するよう分子層レベルで膜厚制御されるととも に, 走行層 $\mathrm{W}_{\mathrm{tr}}$ がナノメートル精度で制御された多層成長 層が必要不可欠となる. 我々は, タンネットダイオード多層 構造を $\mathrm{GaAs}$ の分子層エピタキシー(MLE)により，1 nm 以 下の精度で形成する技術を開発した。

GaAs の MLE は, 図 3 に示すように, 原料としてトリメ チルガリウム (TMG)やトリエチルガリウム (TEG)を所定の 基板温度の基板結晶上に供給し， Ga 化合物の単分子吸着層 を形成した後, $\mathrm{Ga}$ 化合物ガス排気の後に $\mathrm{AsH}_{3}$ を供給し, 単分子層 GaAs 成長層を自律的に 1 層ずつ形成するという究 極の膜厚制御性を実現した完全結晶成長法である.さらに同 方法における不純物添加法では不純物の化合物ガスを表面化 学反応制御によって, After $\mathrm{AsH}_{3}$ モードにより As 面上に 選択的に生じさせたり，あるいは After TEG モードにより $\mathrm{Ga}$ 面上に選択的に生じさせ，あるいはそれぞれノンストイ キオメトリの度合いを制御した成長表面での吸着反応を行わ せる方法により，従来法よりはるかに低温でありながら $\left(265^{\circ} \mathrm{C}\right)$, 高濃度不純物添加する手法を実現している.この 方法によれば, 不純物プロファイルの急峻な高濃度不純物添 加によるトンネル注入層と, ナノメートルオーダーの走行層 を, 制御性よく作製できるためテラヘルツ発振可能なタンネ ット素子構造を形成できる.

図 4 に MLEにより試作したタンネットダイオードのエピ 構造を示した. このダイオードチップはダイシング, さらに はサイドエッチングにより， $0.1 \times 0.1 \times 0.01$ (単位 $\mathrm{mm}$ ) 以下 の微小ダイオードに仕上げている. タンネット発振器キャビ ティ内部の走査型電子顕微鏡による観察結果を同図に示し た. 微小チップ化されたエピ構造は, メタライズ工程を経て ダイヤモンドヒートシンク上にマウントされる. 共振器は, ダイオードをマウントするステム, 駆動電流を供給するバイ アスピン，共振調整用のチューナブルショートから構成され 


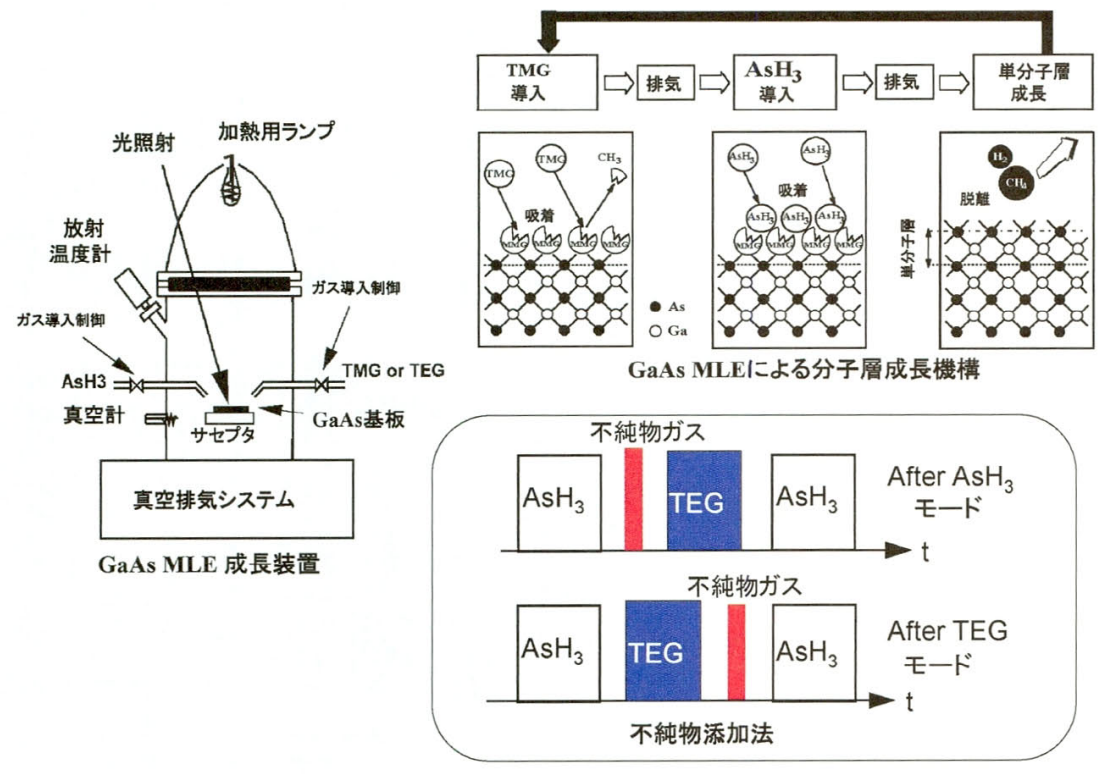

図 3 GaAsの分子層エピタキシャル 成長技術.

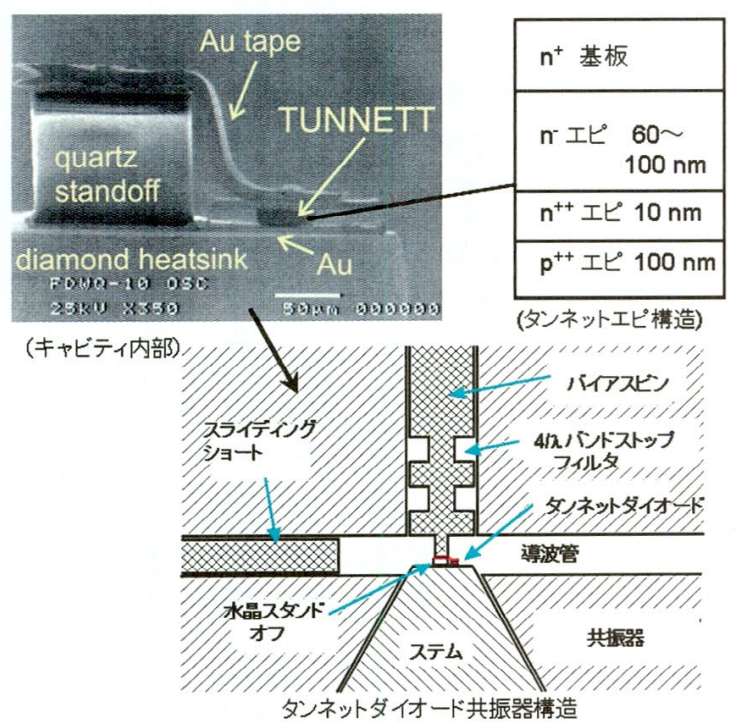

図 4 タンネットダイオードエピ構造と共振器内部構造.

る.

タンネットダイオードの発振特性は, $300 \mathrm{GHz}$ 屯での測 定は八ーモニックミキサとスペクトラムアナライザの組及合 わせによって測定されるが，サブテラヘルツ帯のタンネット ダイオード発振は, 図 5 に示すように検波器にシリコンボロ メータ $(4.2 \mathrm{~K}$ 冷却) を用いた測定システムを構築し測定を行 った。タンネットダイオード発振器からの発振波はホーンア ンテナによって空中に伝搬され，2枚の樹脂製レンズで集光 しシリコンボロメータで出力検出される. 発振周波数は, 2 枚の樹脂製レンズ間にファブリペロー干渉計設置し，片方の メッシュミラーを走査し, ボロメータ出力の peak to peak 間隔を測定することにより周波数を求めた．この測定系によ り, テラヘルッ帯までのタンネット発振周波数測定が可能に なった．WR2.2 (268-500 GHz，導波管 $0.559 \times 0.279 \mathrm{~mm})$ の共振器構造を用いたタンネットダイオード発振器の外観図

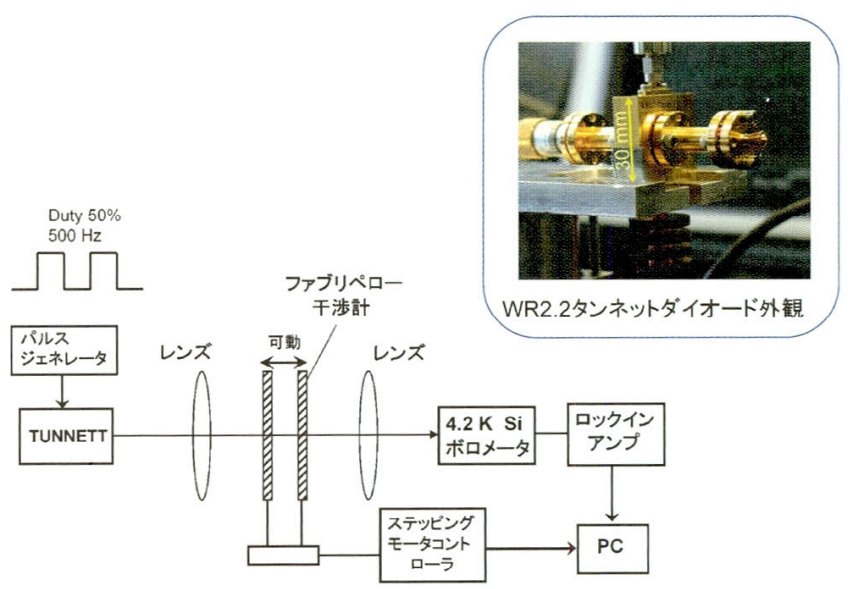

図 5 サブ $\mathrm{THz}$ タンネットダイオードの発振周波数測定.

を同図に示した。 $30 \mathrm{~mm} \times 80 \mathrm{~mm}$ 程度の大きさの単一 DC 電源による, 室温連続発振する小型発振器の試作が実現され た。

図 6 にWR1.5 (393-750 GHz，導波管 $0.381 \times 0.191 \mathrm{~mm})$ およびWR1.0 (590-1100 GHz，導波管 $0.254 \times 0.127 \mathrm{~mm})$ の共振器構造を用いた場合の発振スペクトラムである. 同一 のタンネットダイオードエピ構造を用い，それぞれ 510 $\mathrm{GHz}$ ，扔上び $706 \mathrm{GHz}$ の基本波連続発振を確認している. また，それぞれの発振において発振周波数がバイアス電流值 によって変化することを確認しており，所定の発振周波数を 選択することが可能となる.

これまでに試作・実現したタンネットダイオードの出力と 周波数の関係を図 7 に示した。これらはすべて室温下におい て連続発振して抢り, 最高発振周波数は $708 \mathrm{GHz}$ である. 出力に関しては, $100 \mathrm{GHz}$ までは $10 \mathrm{dBm}(10 \mathrm{~mW}), 200$ $\mathrm{GHz}$ では $0 \mathrm{dBm}(1 \mathrm{~mW})$ 程度, $600 \mathrm{GHz}$ までは $-44 \mathrm{dBm}$ を 実現している.タンネットダイオードにより超小型・高出力 の発振器が実現でき, 広い周波数範囲で所望の周波数を選択 

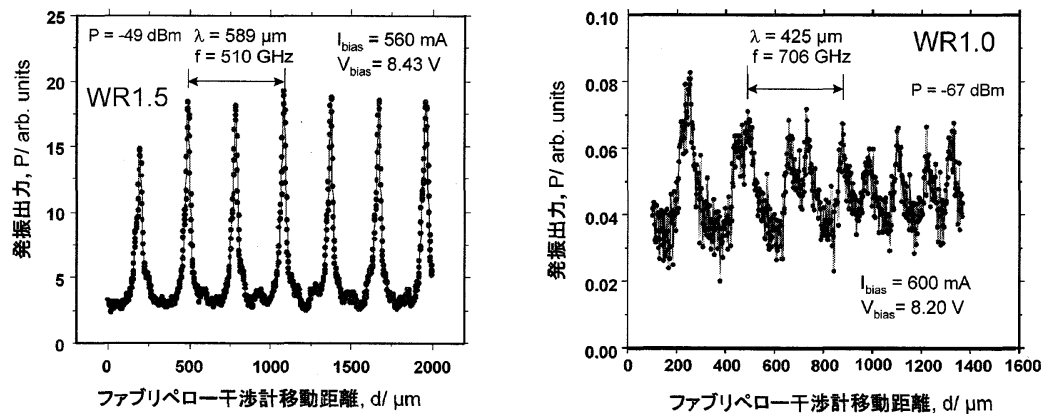

図 6 タンネットダイオードからの 発振スペクトラム。

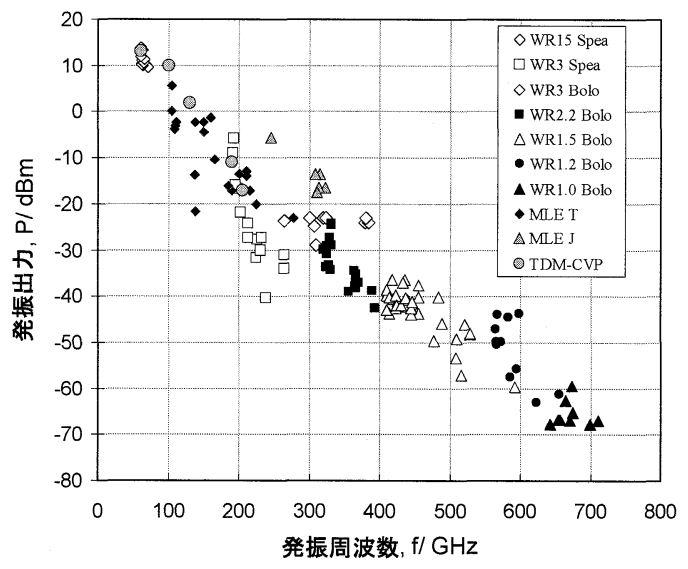

図 7 試作・実現したタンネットダイオードの出力と 周波数の関係.

的に作製する技術が整備されつつある.図中に示したよう に, タンネット発振器は軽量・小型・量産可能な素子であ り，また使用環境温度変化の影響を受けにくい電子デバイス としての性質を兼ね備えている.

タンネットダイオード発振器 $(\mathrm{WR}-3)$ のフリーランニング 時の発振特性の実測においては, タンネットバイアス条件 8 $\mathrm{V}, 350 \mathrm{~mA}$ 印加において, 出力 $0 \mathrm{dBm}(1 \mathrm{~mW})$, 発振周波数 安定性 $\pm 1 \mathrm{MHz} / \mathrm{hr}$, 出力安定性 $\pm 1 \% / \mathrm{hr}$ であった.

\section{4. 小型イメージングシステムの構築}

タンネットダイオード発振器の単一電源による簡便な制御 性, 広帯域性, 発振器のコンパクト性, および優れた周波数 と出力の安定性を生かし, 小型イメージングシステムを構築 した. 図 8 に示したのは構築した透過および反射イメージン グシステムの概略図である(18)。ロックイン検出を行うた め, タンネットダイオードは $4 \mathrm{kHz}$ でパルス駆動した．テ フロンまたはポリエチレン製のレンズを用い光学系を構成し た. 光源としてのタンネット発振器を用いること, 抢よび検 出器としてショットキーバリアダイオード検出器を用いるこ とにより光学系システム全体を大幅に縮小し, 従来のデスク トップサイズからA4 サイズまで小型化を実現した。また高 解像度を実現するためにアパーチャを設置し，ビーム径を波 長以下まで微小化し, 高分解能を実現している. 測定試料は $\mathrm{X}-Z$ スキャンされ各点ごとの透過および反射強度をコンピ ュータに取り込み画像を得た。このシステムを用い, 200

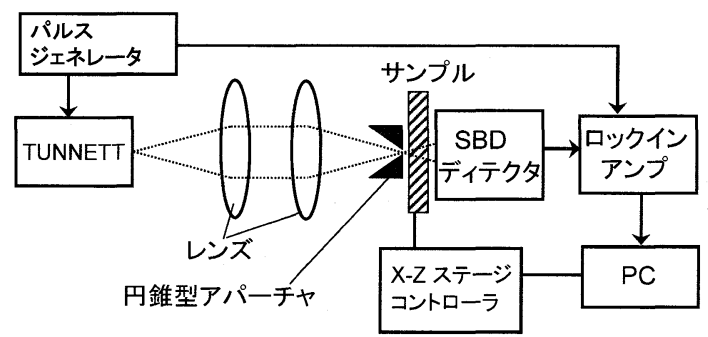

透過イメージングシステム

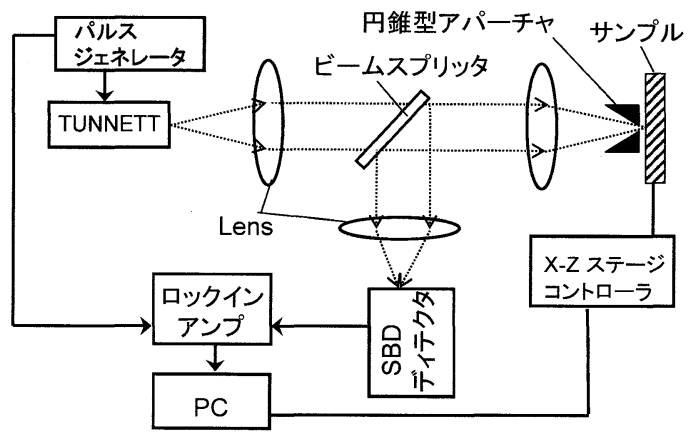

反射イメージングシステム

図 8 透過および反射イメージングシステムの概略図.

$\mathrm{GHz}$ 付近の電磁波を用いた際の空間分解能を測定した。図 9 に，透過および反射イメージングにおけるアルミニウムを パターンニングした高抵抗シリコンウェハのナイフェッジ測 定で得られた空間分解能の実測結果を示す. 高抵抗シリコン ウェハはこの周波数の電磁波透過性に優れ，アルミニウム蒸 着薄膜は電磁波を反射する.アパーチャの開口径を変えた際 の, 透過および反射イメージングシステムで解像度を得た. アパーチャ開口径が $1 \mathrm{~mm}$ の時, 透過光学系における空間分 解能は $440 \mu \mathrm{m}$ 程度, 反射光学系では $350 \mu \mathrm{m}$ 程度となって いる.アパーチャ径を $1 \mathrm{~mm}$ 以下とすることにより，反射測 定では分解能が $300 \mu \mathrm{m}$ にまで達し, 分解能は $5 / \lambda$ 程度が得 られていることから, 波長 $\lambda$ よりも十分に小さいサイズの アパーチャによる近接場光を利用したイメージングの可能性 が示唆されている. 一方, アパーチャ径の減少に伴い顕著に 透過強度が低下し，アパーチャ $2 \mathrm{~mm} \phi$ のサブテラヘルツ波 透過強度を 1 とすると, $1 \mathrm{~mm} \phi$ で透過強度 $0.12,0.7 \mathrm{~mm} \phi$ では透過強度 0.006 まで低下する。このことから，使用する 発振器の強度, 必要とされる分解能, および検出器の種類に よって光学系の構成要素が決定される. 
イメージングの実施に先立ち，各種物質の透過特性を測定 し, 各媒質によりイメージング時の透過強度が確保されるか ゼうかの測定を行った。測定では㘠 8 の透過イメージング

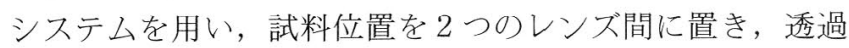
強度を測定した。図10に示したのは閒封後 2 ケ月程度室内 放置したコピー用紙と開封直後のコピー用紙の $196 \mathrm{GHz}$ 電 磁波を用いた吸光度依存性を表している。これより，200 $\mathrm{GHz}$ 付近の電磁波はコピー用紙 100 枚以上を透過し, 開封後 時間の経過したもので顕著に吸光度が大きくなることから， 紙類の含水率变化に高感度である. 同様の優れた透過性は紙 類の他に，木材，セラミックス，抢よびコンクリート材料で 確認され，媒質を透過する周波数を用いることにより各媒質 内部に存在する構造欠陥や異物の混入などに対する非破壊検 査への適用の可能性が高まった。

図11に示したのは，タンネットダイオードによるICカー ド (Suica)の透過抢よび反射イメージング画像を示してい る. 透過抢よび反射イメージのどちらも $196 \mathrm{GHz}$ の電磁波 を用いた測定となっているが両者上も波長 $(1.5 \mathrm{~mm})$ よりも 高い分解能が実現されている．特に反射イメージングではル ープ状アンテナ細線やICチップの形状などが高分解能で画

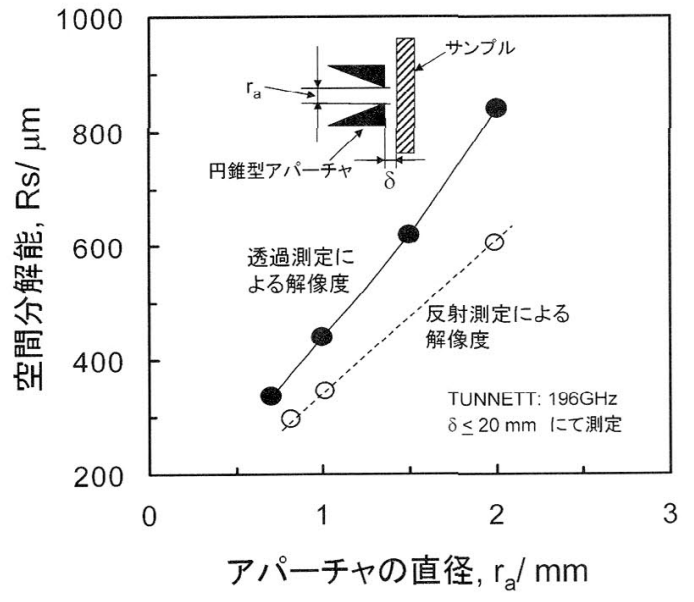

図 9 透過抒よび反射イメージングに抢悾間分解 能の测定結果.

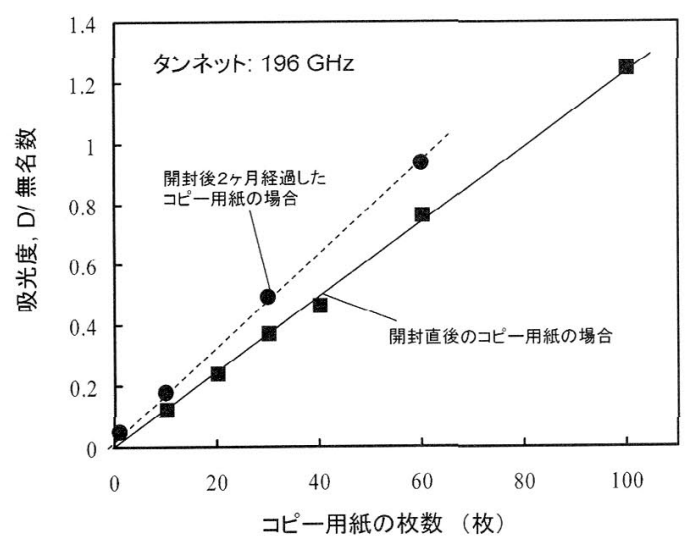

図10 紙類の透過特性.
像化されている。この例のように，タンネットを用いたイメ ージングにより, 軽量・小型のシステムで未開封による物体 内部の画像情報を得ることができ，物質内部の詳細情報が得 られるものと考えられる。金属などの分布状況に関しては， 透過イメージと反射イメージは画像的にネガとポジの関係に あるが，物質表面付近の情報は反射イメージングが適して抒 り，表面から深い物質内部の情報は透過イメージングが適し ている.このように種々の物質に関し, 透過画像と反射画像 を組み合わせ, 詳細な内部構造イメージングが可能となる。

図12に示したのは，封筒中の梱包物に関する透過および反 射イメージング画像の周波数依存性を表している. 4 枚の印 刷された紙をステープラーやクリップで束ね, 表面にはペー パーカッターの刃, 裏面には直径 $0.5 \mathrm{~mm}$ の鉛筆芯を透明テ 一プなどで固定しこれを厚手の封筒中に封じた。 タンネット ダイオードからの発振周波数上して，62，189，执よび 466 $\mathrm{GHz}$ を用い, 図 8 に示したイメージングシステムにて透過 および反射イメージング画像を得た. $62 \mathrm{GHz}$ (波長 $4.8 \mathrm{~mm}$ ) では優れた透過性はあるものの, 空間分解能が劣化し, 相包 物の形がぼやけている. $189 \mathrm{GHz}$ (波長 $1.6 \mathrm{~mm}$ ) では透過性 能と有しつつ分解能が改善されており，1 mm 以下の相包物 の形が精度よく画像化されていることがわかった。 また透過 画像では, 内部相包物に貼り付けた薄手のテープ(スコッチ テープ)が高いコントラストで画像化されることを確認し た．このような透過性物質のイメージングに関しては特定波 長を選択することで, 赤外〜X 線領域で観察が難しい特定 物質に関して，テラヘルツ帯の特定波長を用いることで分光 学的イメージングが有効である. $466 \mathrm{GHz}$ (波長 $0.64 \mathrm{~mm}$ ) を 用いた透過イメージングでは空間分解能の向上は顕著である が，束ねた紙間の干渉が現れ，たわみの状況が画像化されて いる. また，反射画像では梱包物の表面付近の状況が優先的 に画像化され，裏面付近は画像化がなされて抢らず，高い周 波数では電磁波が梱包物で顕著に減衰するこ上を表している.

\section{5. 非破壊検査への応用}

図13に示したのは，189 GHzの電磁波を用いた場合の木 材の透過イメージング画像である。同図に示したように木材

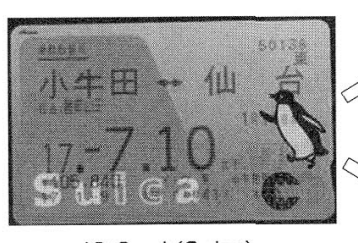

IC Card (Suica)

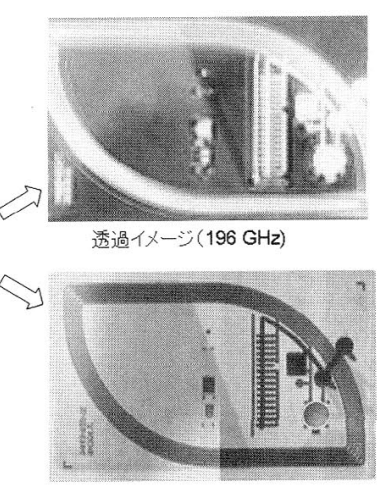

反射イメージ(196 GHz)
図11 IC カード (Suica)の透過抢よび反射イメージング. 


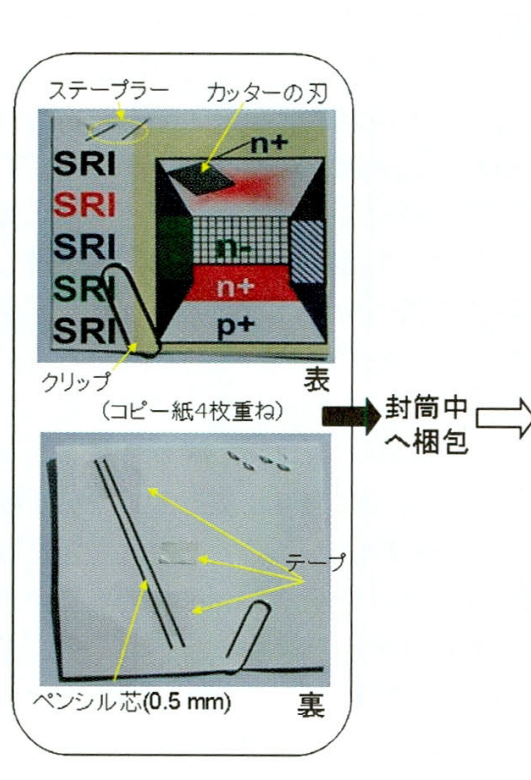

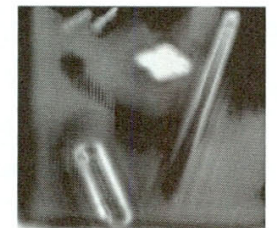

透過イメージ(62 GHz)

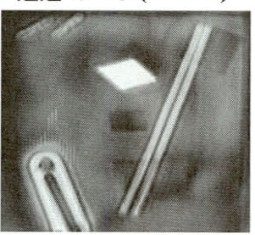

透過イメージ(189 GHz)

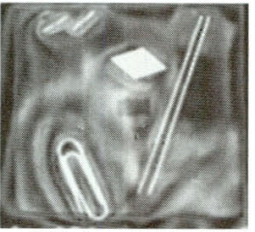

透過イメージ $(466 \mathrm{GHz})$

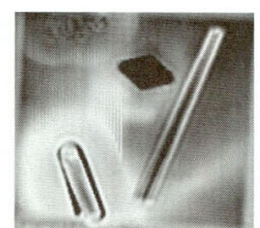

反射イメージ $(62 \mathrm{GHz})$

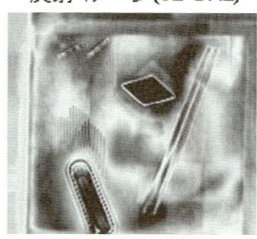

反射イメージ $(189 \mathrm{GHz})$

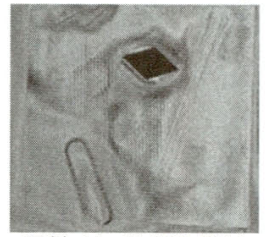

凤射イメージ( $(466 \mathrm{GHz})$
図12 封筒中梱包物の透過抢よび 反射イメージング.
(厚さ $25 \mathrm{~mm}$ )の節部付近は強い吸收特性を示し,このため 透過画像上で節の形状が白くパターン化されている。 また各 種木材に関して, 木目付近で透過率の変化が生じ, 内部構造 を反映した透過画像が得られている.

この技術を応用すれば，木材中に存在する割れ，空洞，死 節などの構造欠陥の画像化と, 含水率や密度分布の画像化が $1 \mathrm{~mm}$ 精度で可能となる. 本来, 製材は大きな力を受ける構 造用材として使われ，JAS 規格による等級格付けはマク口 的な機械等級区分が採用され，高級木材に限って X 線等を 用いたミクロ的な内部構造検査と，インピーダンス測定やマ イクロ波を用いた含水率のマクロ的な測定が実施されてい る.タンネットによる最適波長を用いたイメージングはこれ までに実現不可能であった，死節やひび割れ箇所の特定と含 水率 ·密度分布を同時に測定可能なミク口的検査法として有 望である。

異物入りコンクリート材料に関し，透過イメージングによ り非破壊検査を試みた結果を図14に示した。厚さ $25 \mathrm{~mm}$ の コンクリート材料を設打する際に鉄板，ダンボール，打よび ベニア板を混入させ固化し，乾燥後に透過イメージングにて 内部非破壊検査を行った。金属板では電磁波の透過が生じな いため, 形状が高コントラストで画像化され, ダンボールで はコンクリートとほぼ同様の透過強度であるが，ダンボール の輪郭が明確化された。 またべニア板では明確な形状と共 に，中間的な透過特性が観察されている。

木材に関しては， $60 \sim 200 \mathrm{GHz}$ の範囲で透過能に顕著な 違いはなく，スギ材などで $10 \mathrm{~cm}$ 程度までの透過特性を確 認して抢り，JAS 規格の一つである $15 \mathrm{~cm}$ 厚久の木材に適 用できる可能性が高い。一方，コンクリート材料に関して は, 電磁波の侵入深さは周波数に大きく依存し，高分解能の 得られる $200 \mathrm{GHz}$ 付近では $20 \mathrm{~mm}$ 程度, $60 \mathrm{GHz}$ 付近では $100 \mathrm{~mm}$ 程度が観測されており, 実用化のためには侵入深さ をさらに深くできる周波数の探索と発振器出力の高出力化が 課題となっている.

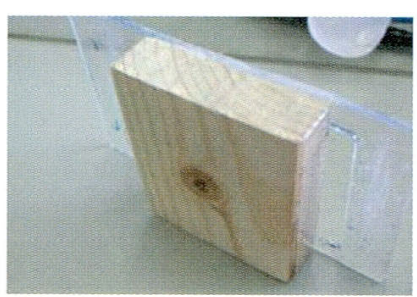

木材（厚さ25 mm）

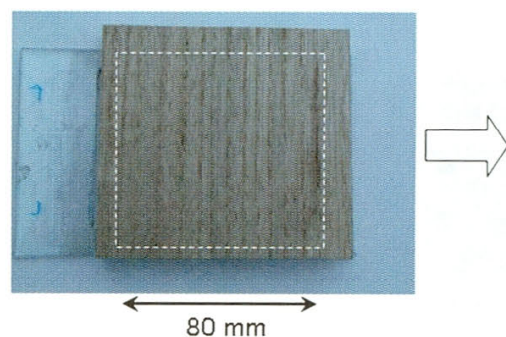

材質: 栗(厚さ15 mm)

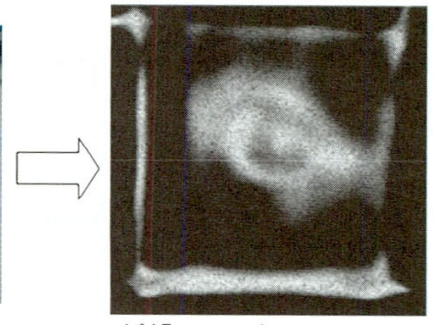

透過イメージ $(189 \mathrm{GHz})$

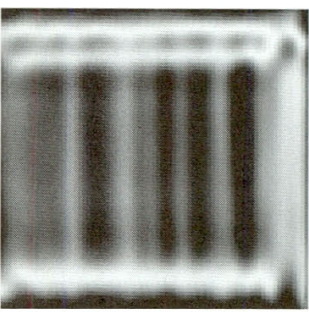

透過イメージ(189 GHz)
図13 木材の透過イメージング.

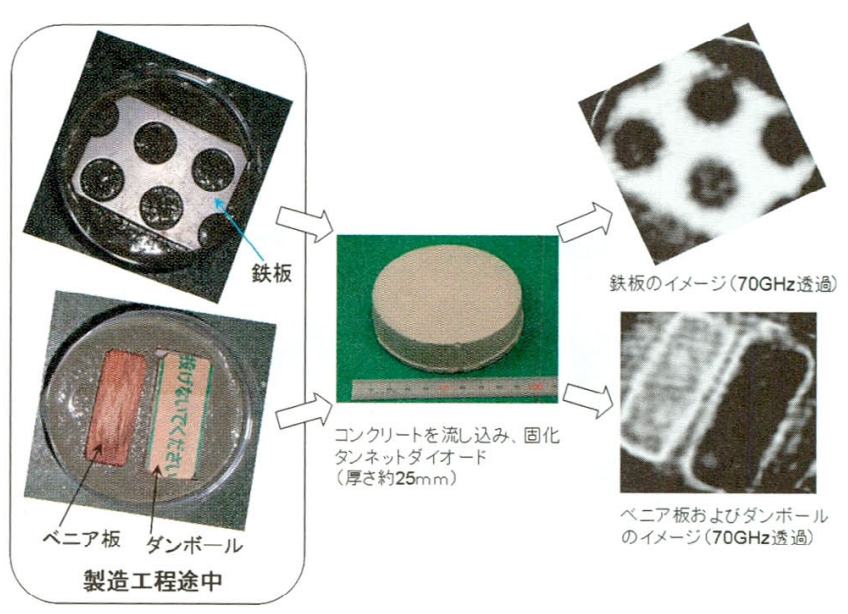

図14 コンクリート材料の透過イメージング. 
テラヘルツ波を用いたイメージングは大別して 2 つ方 法があると思われる．1つは特定物質に特有のテラヘルツ帯 吸收波長を利用して物質を特定し，その分布状況を画像化す る分光イメージング。もううつは，媒質を透過するテラヘル ツ波の周波数带の中で最も波長の短い電磁波を用い，媒質内 部に含まれる構造欠陥や異物の検出を非破壊で行う力法であ る。何れの場合も，厳密に周波数依存性を測定し，適合する 周波数を選択した高分解能イメージングを実現することで， 幅広い応用への展開が期待できる.

\section{6. ま め}

1958年に初めて提案したタンネットダイオードは, GaAs 分子層エピタキシャル成長技術を適用することによって 700 $\mathrm{GHz}$ を超える基本波室温連続発振を実現し, テラヘルツ波 発振可能な電子デバイスとして世界最高周波数に達してい る. タンネットダイオードは低雑音素子であり, ワイヤレス 通信に適用可能な発振素子としての研究を進めているところ であるが，広い周波数範囲の発振を素子構造の選択によって 実現できることから，小型・簡易なテラヘルツイメージング 光源としての有効性を探索した.

タンネットの発振周波数を選択したイメージングにより梱 包物，木材およびコンクリート中の異物や金属の探知亦るい は，ひび割れ検出などの可能性を検証した。この方法は表面 から観察できない欠陥，異物，あるいはひび割れなどを高分 解能に検出でき，また赤外線よりはるかに深部の情報が得ら れるという特徵がある. タンネットの発振周汥数を選ぶこと により所望の深さの情報を得ることが可能になることから， 木材やコンクリートに対する非破壊検査として適用できる可 能性がある。

本研究に関して，タンネットダイオードの開発，基本設 計，抢よび応用展開に関するあらゆる観点から御指尊いただ いた財団法人半導体研究振興会の西澤潤一名誉所長に深く感 謝いたします。

なお，本研究の一部は文部科学省プロシェクト「医療用テ ラヘルツ光診断システムの開発」および日本学術振興会の学 術創成研究「フォノン工学| (No. 13GS0002)による助成に よって行われた。

\section{文献}

（1）渡辺 寧，西澤潤一：昭和 28 年度電電公社委託研究報告 (1953)，および J. Nishizawa and Y. Watanabe: High frequency properties of the avalanching negative resistance diode, Sci. Rep. Res. Inst. Tohoku Univ. B-(Comm), Sendai, Japan, 10-2 (1958), 91-108.

(2) T. Okabe, S. Takamiya, K. Okamoto and J. Nishizawa: Bulk

oscillation by tunnel injection, IEDM Tech. Dig., Dec., (1968).

(3) J. Nishizawa, H. Abe and T. Kurabayashi: Molecular layer epitaxy, J. Electrochem. Soc., 132(1985), 1197-1200.

(4) J. Nishizawa, T. Kurabayashi, P. Płotka, H. Kikuchi and T. Hamano: Self-Limiting Growth of $\mathrm{G} a \mathrm{~A}$ s with doping by Molecular Layer Epitaxy Using Triethyl-gallium and $\mathrm{AsH}_{3}$. J. Crystal Growth, 244(2002), 236-242.

( 5 ) P. Płotka, J. Nishizawa, T. Kurabayashi and H. Makabe: 240325-GHz GaAs CW fundamental-mode TUNNETT diodes fabricated with molecular layer epitaxy, IEEE Trans. Electron Devices, 50-4 (2003), 867-873.

(6) J. Nishizawa, P. Płotka, H. Makabe and T. Kurabayashi: 290$393 \mathrm{GHz} \mathrm{CW}$ fundamental-mode oscillation from GaAs TUNNETT diode, Electronics Letters, 41(7) (2005), 441-442.

(7) J. Nishizawa, P. Płotka, H. Makabe and T. Kurabayashi: GaAs TUNNETT Diodes Oscillating at 430-655 GHz in CW Fundamental Mode, IEEE Microwave and Wireless Components Letters, 15-9(2005), 597-599.

（8）西澤潤一：電子科学，4(1963)，17，および西澤潤一：電子技 術, 7(1965), 101.

(9) K. Suto and J. Nishizawa: IEEE J. Quantum Electron., 19 (1983), 1251

(10) T, Tanabe, K. Suto, J. Nishizawa, T. Kimura and K. Saito: J. Appl. Phys., 93(2003), 4610.

(11) J, Nishizawa, K. Suto, T. Sasaki, T. Tanabe and T. Kimura: J. Phys., D: Appl. Thys., 36(2003), 2958.

(12) K. Kawase, J. Shikata, K. Imai and H. Ito: Appl. Phys. Lett., 78(2001), 2819

(13) T. Taniuchi, S. Okada and H. Nakanishi: J. Appl. Phys., 95-11 (2004), 5984.

(14) E. R. Brown, J. R. Sönderatröm, C. D. Parker, L. J. Mahoney, K. M. Molvar and T. C. WcGill: Appl. Phys. Lett., 58 (1991), 2291.

(15) N. Orihashi, S. Suzuki and M. Asada: Appl. Phys. Lett., 87 (2005), 233501

(16) R. Köhler, A. Tredicucci, F. Beltram, H. E. Beere, E. H Linfield, A. G. Davies, D. A. Ritchie, R. C. Iotti and F. Rossi: Nature, 417-9(2002), 156.

(17) B. S. Williams, H. Callebaut, S. Kumar, Q. Hu and J. L. Reno: Appl. Phys. Lett., 82-7(2003), 1015.

（18）西澤潤一，倉林 徹：「タンネットダイオード発振器を用いた サブテラヘルツイメージング」信学技報, IEICE Technical Report, ED2005-241(2006), 17-22.

\section{合林 徹}

1986年 東北大学大学院工学研究科電子工学専攻博士後期課程修了

1987年〜1992年 科学技術庁創造科学技術推進事業テラヘルップロジェクト 研究員出向

1992年～1998年 東北大学大学院工学研究科講師

1998年 2001年 通信・放送機構仙台リサーチセンターサブリーダ・

2000年 4 月上り 財団法人半道体研究振興会主任研究員

専門分野：結晶成長，テラヘルッデバイス

分子吸着を利用した低温化した分子層成長技術に上り，テラヘルツ発生可能 な電子デバイスが実現できる。

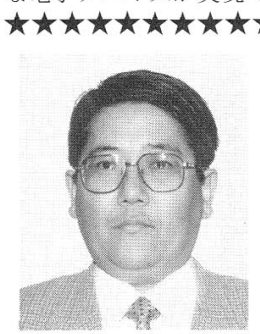

倉林 徹

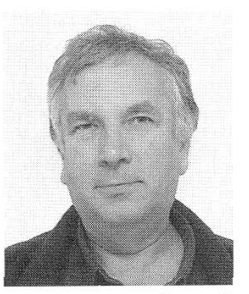

ピョートル・プロトカ 